\title{
DETERMINAN KESUKSESAN SISTEM INFORMASI DI RSUD Dr. MOEWARDI
}

\author{
Ermiati $^{1}$ \\ Program Studi Manajemen, Fakultas Ekonomi Universitas Setia Budi Surakarta \\ (ermyenr@gmail.com) \\ Didik Setyawan ${ }^{2}$ \\ Program Studi Manajemen, Fakultas Ekonomi Universitas Setia Budi Surakarta \\ (didiksetyawan1977@gmail.com) \\ Waluyo Budi Atmoko ${ }^{3}$ \\ Program Studi Manajemen, Fakultas Ekonomi Universitas Setia Budi Surakarta \\ (waluyobudiatmoko@gmail.com)

\section{Sugiyarmasto 4} \\ Program Studi Manajemen, Fakultas Ekonomi Universitas Setia Budi Surakarta \\ (syarmasto@gmail.com )
}

\begin{abstract}
The study of success information system organized is still a study important in researchs systems information. It is caused by existence of the diversity of the results of research on the success of the the information system in organizations on various research an object that impact on variable user and the weapons of the analysis that adapted to the purposes of research (Delone \& Mclean, 2003; Wu \& Wang, 2006; Holsapple \& Le-post, 2006). The purpose of this research is to test antaseden in the form of satisfaction in building intention use the information at RSUD Dr. Moewardi Surakarta. Research sample areas are employees at RSUD Dr. Moewardi as many as 200 respondents. Sampling technique use two stage clusters random sampling, a measuring instrument use testing spss and the testing of hypotheses use SEM (Structural Equation Modelling) with software AMOS. Based on the results of the analysis showed that all hypothesis supported that is significant the connection between satisfaction with the intention to continue, a significant relation between quality information with satisfaction user, a significant relation between quality the system with satisfaction users, and a significant relation exists between the quality of services with satisfaction users information system .
\end{abstract}

Keywords: The quality of information, the quality of the system, the quality of services, user satisfaction, intention to continue the the information system.

\section{A. PENDAHULUAN}

Studi tentang kesuksesan sistem informasi di organisasi masih menjadi kajian penting dalam penelitian-penelitian sistem informasi. Hal ini disebabkan adanya keragaman hasil penelitian tentang kesuksesan sistem informasi di organisasi pada berbagai obyek penelitian yang berdampak pada pengguna variabel dan alat analisis yang disesuaikan dengan tujuan penelitian (Delone dan McLean, 2003., Wu dan Wang, 2006., Holsapple dan Le-post (2006). Maka dalam studi ini merekonstruksi model penelitian kesuksesan sistem 
informasi yang dikembangkan oleh Delone dan McLean (2003) dengan menyesuaikan obyek penelitian yang digunakan.

Penggunaan sistem informasi memiliki dampak yang dramatis pada operasi bisnis. Pengukuran keberhasilan atau efektivitas sistem informasi masih penting untuk pemahaman pengguna dalam hal penilaian, tindakan manajemen dan investasi sistem informasi (Delone dan McLean, 2003). Grove et al (1996) menyebutkan perlunya pengembangan dan mengusulkan kerangka kerja yang alternative untuk mengukur efektivitas sistem informasi

Berbagai penelitian memiliki keragaman hasil tentang kesuksesan sistem informasi (Delone dan McLean,2003;Wu dan Wang, 2006). Studi yang dilakukan oleh Delone dan McLean (2003) dalam pembentukan niat untuk menggunakan yang dipengaruhi oleh kepuasan pengguna sistem informasi sebagai variabel mediasi yang dibentuk oleh kualitas sistem, kualitas informasi, kualitas layanan, dan manfaat tetap. Studi lain yang dilakukan oleh Wu dan Wang (2006) dengan memodifikasi model yang dikembangkan oleh Delone dan McLean (2003) dengan penggunaan sistem manajemen pengetahuan (KMS) didapatkan dari kepuasan pengguna, kualitas sistem, dan kualitas informasi. Hasil tersebut dapat disimpulkan kesuksesan sistem informasi dalam pembentukan niat menggunakan masih menjadi kajian penting.

Bahasan tentang kesuksesan sistem informasi terdapat perbedaan hasil yang dilakukan oleh Holsapple dan Le-post (2006) pada siswa dengan pembelajaran offline diperoleh hasil kualitas sistem, kualitas informasi, dan manfaat tetap tidak signifikan, sedangkan kualitas mutu, kepuasan pengguna, dan niat menggunakan mendapatkan hasil yang signifikan. Hasil studi lain dengan variabel sama yang dilakukan oleh Holsapp dan Le-post (2006) pada siswa dengan pembelajaran online menunjukan hasil yang signifikan.Keragaman hasil tersebut peneliti perlu melakukan konfirmasi studi tentang model kesuksesan sistem informasi yang dikembangkan oleh Delone dan McLean (2003) dengan melakukan penyesuaian sesuai obyek yang digunakan dan niat melanjutkan sebagai ukuran kesuksesan sistem informasi.

Berbagai studi kesuksesan sistem informasi dalam pembentukan niat dipengaruhi oleh beberapa variabel yaitu kualitas sistem, kualitas informasi, kualitas layanan, pengguna, kepuasan pengguna dan manfaat tetap sebagai variabel independen (Delone dan McLean, 2003). Namun penelitian pembentukan niat melanjutkan yang akan dilakukan oleh peneliti dipengaruhi oleh kepuasan pengguna, kualitas informasi, kualitas sistem, dan kualitas layanan sebagai variabel independen. Hal ini didasarkan pada studi Petter dan McLean (2009) menggunakan meta-analisis, dimana terdapat hubungan yang signifikan antara kepuasan pengguna dengan niat menggunakan, kualitas sistem dengan niat menggunakan, kualitas informasi dengan niat menggunakan, 
sedangkan kualitas layanan dengan niat menggunakan tidak terdapat hubungan yang signifikan. Maka kajian kesuksesan sistem informasi pada obyek yang berbeda masih diperlukan untuk mendapatkan model yang diterapkan pada berbagai obyek amatan.

Berdasarkan review jurnal yang telah dilakukan, peneliti mengajukan penelitian kesuksesan sistem informasi yang difokuskan pada niat untuk melanjutkan penggunaan sistem informasi bagi petugas RSUD Dr. Moewardi. Penelitian ini dirasa penting dalam pengembangan keilmuan karena masih belum ada penelitian kesuksesan sistem informasi dengan obyek rumah sakit yang memfokuskan pada niat untuk melanjutkan penggunaan sistem informasi.

\section{B. KAJIAN LITERATUR DAN PENGEMBANGAN HIPOTESIS}

\section{Niat untuk Melanjutkan}

Niat secara umum dijelaskan oleh Venkatesh et al., 2003 yang mendefinisikan bahwa niat adalah tingkat dimana individu telah merencanakan untuk melakukan atau tidak melakukan sesuatu di masa depan (Sancata dan Subagio, 2014). Penjelasan tersebut memberikan arti bahwa niat adalah sikap individu untuk melakukan tindakan dimasa depan.

Perkembangannya berikutnya niat diterapkan pada penggunaan sistem informasi. Technologi Acceptance Model (TAM) yang dikembangkan oleh Davis (1989) yang mengadopsi model Theory of Reasoned Action (TRA) menjelaskan niat menggunakan sistem informasi adalah teori tindakan yang beralasan dengan satu premis bahwa reaksi dan persepsi seseorang terhadap sesuatu hal yang akan menentukan sikap dan perilaku orang tersebut. Maka niat menggunakan sistem informasi didefinisikan sebagai suatu ukuran tindakan atau perilaku individu yang memberikan reaksi dan persepsi untuk tetap dan menerima penggunaan aplikasi sistem informasi.

Niat untuk melanjutkan di bentuk oleh beberapa variabel yaitu ,kemudahan, keinginan, kegunaan, kesenangan, kepuasan pengguna, kualitas sistem, kualitas informasi, dan kualitas layanan (Delone dan McLean, 2003; Davis, 1989). Namun dalam studi ini hanya menggunakan variabel pembentuk niat melanjutkan yang dipengaruhi oleh variabel kepuasan penggunaan sistem informasi, kualitas informasi, kualitas sistem, dan kualitas layanan. Semua variabel yang digunakan dalam penelitian menjadi variabel penting dalam pengukuran kesuksesan sistem informasi (van Dyke et al, 1997; petter dan McLean, 2009). Hal ini didasarkan pada berbagai penelitian yang menunjukan hubungan yang signifikan antara kepuasan, kualitas informasi, kualitas system, dan kualitas layanan dengan niat untuk melanjutkan (Petter dan McLean, 2009., Wu dan Wang, 2006., Delone dan McLean, 2003., Holsapple dan Lee-post, 2006).

\section{Kepuasan Pengguna}

Kepuasan adalah seberapa jauh pengguna puas dan percaya terhadap 
sesuatu yang digunakan untuk memenuhi kebutuhan (Ives, et al., 1983). Kepuasan menurut Olliver (1999) adalah evaluasi kesesuaian yang dipersepsikan antara harapan sebelumnya dengan kinerja produk. Delone dan McLean (2003) menyatakan bahwa kepuasan pengguna sistem informasi adalah sejauh mana aplikasi mampu membantu pengguna dan membuat nilai bagi pelanggan internal maupun pelanggan eksternal. Penjelasan tersebut kepuasan penggunaan sistem informasi dapat dimaknai sebagai tanggapan akhir tentang sejauh mana aplikasi teknologi informasi mampu membantu dan memberikan nilai kepada pelanggan internal maupun pelanggan eksternal.

Berbagai studi menunjukan adanya hubungan yang kuat antara kepuasan terhadap niat untuk melanjutkan (Delone dan McLean, 2003; Petter dan McLean, 2009; Widiana et al., 2012). Penelitian yang dilakukan oleh Petter dan McLean (2009) menggunakan meta-analisis, dimana kepuasan penggunaan sistem informasi mempunyai hubungan yang signifikan terhadap niat untuk melanjutkan. Kemudian studi yang dilakukan oleh Delone dan McLean (2003) dengan menguji obyek penelitian serqualitas, diperoleh hasil kepuasan penggunaan sistem informasi mempunyai hubungan yang signifikan terhadap niat untuk melanjutkan. Hasil yang sama juga ditunjukan oleh studi penelitian yang dilakukan oleh Widiana et al. (2012) pada konsumen produk batik online di UKM Jawa Timur, dimana kepuasan pengguna mempunyai hubungan yang signifikan terhadap niat untuk melanjutkan. Berdasarkan studi yang telah diuraikan tersebut peneliti merumuskan hipotesis sebagai berikut :

$H_{1}$ : Kepuasan pengguna sistem informasi berpengaruh positif terhadap niat untuk melanjutkan penggunaan sistem informasi.

\section{Kualitas Informasi}

Kualitas informasi secara umum dijelaskan oleh Negash et al. (2002) mendefinisikan kualitas informasi adalah nilai yang dihasilkan dan dirasakan oleh individu. Definisi ini menunjukkan bahwa kualitas informasi merupakan nilai yang dihasilkan dari sistem informasi yang akurat, tepat waktu, relevan, mudah dimengerti, berhubungan, memiliki nilai, lengkap, pasti, netral, dapat dibandingkan, dan konsisten. Pendapat berbeda diungkapkan oleh Tjakrawala dan Cahyo (2010) menyatakan bahwa kualitas informasi adalah persepsi pengguna seberapa jauh software mampu menyampaikan pengertian atau pesan yang dimaksud atau kualitas output dari software tersebut. Maka kualitas informasi dapat didefinisikan sebagai persepsi pengguna tentang seberapa jauh software mampu memberikan nilai, relevansi, urgensi dari informasi yang dihasilkan.

Berbagai studi menunjukan adanya hubungan yang kuat antara kualitas informasi terhadap kepuasan pengguna sistem informasi (Delone dan McLean, 2003; Wu dan Wang, 2006; Holsapple dan Lee-post, 
2006; Petter dan McLean, 2009). Hal ini ditunjukan oleh penelitian yang dilakukan oleh Petter dan McLean (2009) menggunakan meta-analisis, dimana variabel kualitas informasi mempunyai hubungan yang signifikan terhadap kepuasan pengguna sistem informasi. Kemudian hasil studi penelitian yang dilakukan oleh Wu dan Wang (2006) pada pegawai administrasi di Taiwan, diperoleh hasil variabel kualitas informasi mempunyai hubungan yang signifikan terhadap kepuasan pengguna sistem informasi. Hasil penelitian yang sama juga dilakukan oleh Delone dan McLean (2003) dengan menguji obyek penelitian serqualitas dan Holsapple dan Lee-post (2006) pada pelajar online dan pelajar ofline menyatakan bahwa variabel kualitas informasi mempunyai hubungan yang signifikan terhadap kepuasan pengguna sistem informasi. Berdasarkan studi yang telah diuraikan peneliti merumuskan hipotesis sebagai berikut:

$\mathrm{H}_{2}$ : Kualitas informasi berpengaruh positif terhadap kepuasan pengguna sistem informasi.

\section{Kualitas Sistem}

Kualitas sistem adalah tingkat baik buruknya kumpulan sumber daya seperti manusia dan peralatan yang dibutuhkan individu (Fasihat dan Pertiwi, 2015). Sedangkan penjelasan dari Holsapple dan Lee-post (2006) menyebutkan kualitas sistem terdiri dari empat hal yaitu mudah digunakan (easy to use), user friendly, stabil (stable), aman (secure), dan cepat (fast).
Konsepsi kualitas sistem diterapkan pada penggunaan sistem informasi dimaknai sebagai keakurasian dan efisiensi dari teknologi yang berperan dalam menghasilkan informasi (Tjakrawala dan Cahyo, 2010). Definisi ini menunjukkan bahwa kualitas sistem adalah keakurasian teknologi dalam menghasilkan sistem informasi.

Berbagai studi menunjukan adanya hubungan yang kuat antara kualitas sistem terhadap kepuasan pengguna sistem informasi (Delone dan McLean, 2003; Holsapple dan Lee-post, 2006; Petter dan McLean, 2009). Dalam studi terdahulu yang dilakukan oleh Petter dan McLean (2009) menggunakan meta-analisis, diperoleh hasil variabel kualitas sistem secara signifikan mempengaruhi kepuasan pengguna sistem informasi. Penelitian dengan hasil yang sama juga dilakukan oleh Delone dan McLean (2003) dengan menguji obyek penelitian serqualitas dan Holsapp dan Lee-post (2006) pada pelajar online dan pelajar ofline yaitu kualitas sistem secara signifikan mempengaruhi kepuasan pengguna sistem informasi. Berdasarkan studi yang yang telah diuraikan tersebut peneliti merumuskan hipotesis sebagai berikut:

$\mathrm{H}_{3}$ : kualitas sistem berpengaruh positif terhadap kepuasan pengguna sistem informasi.

\section{Kualitas layanan}

Kualitas layanan secara umum dijelaskan oleh Parasuraman et al. (1985) menyatakan bahwa kualitas layanan 
merupakan konstruk hasil perbandingan antara kinerja dan harapan. Studi lain yang dilakukan oleh Parasuraman et al. (1998) yang menyatakan bahwa kualitas pelayanan merupakan dasar bagi pemasaran jasa, karena inti produk yang dipasarkan adalah suatu kinerja (yang berkualitas), dan kinerjalah yang dibeli oleh pelanggan (Kaihatu, 2008). Petter dan McLean (2009) menyatakan bahwa kualitas layanan merupakan dukungan dari pengguna sistem informasi yang sering diukur dengan respon, kehandalan, dan empati dari dukungan suatu organisasi.

\section{MODEL PENELITIAN}

Definisi ini menunjukkan bahwa kualitas layanan merupakan kualitas yang memberikan dukungan sistem informasi yang diukur dengan respon, kehandalan, empati, ketepatan, adil, tersedia, dan pengetahuan. Berdasarkan studi yang telah diuraikan penulis merumuskan hipotesis sebagai berikut:

$\mathrm{H}_{4}$ : Kualitas layanan berpengaruh positif terhadap kepuasan pengguna sistem informasi.

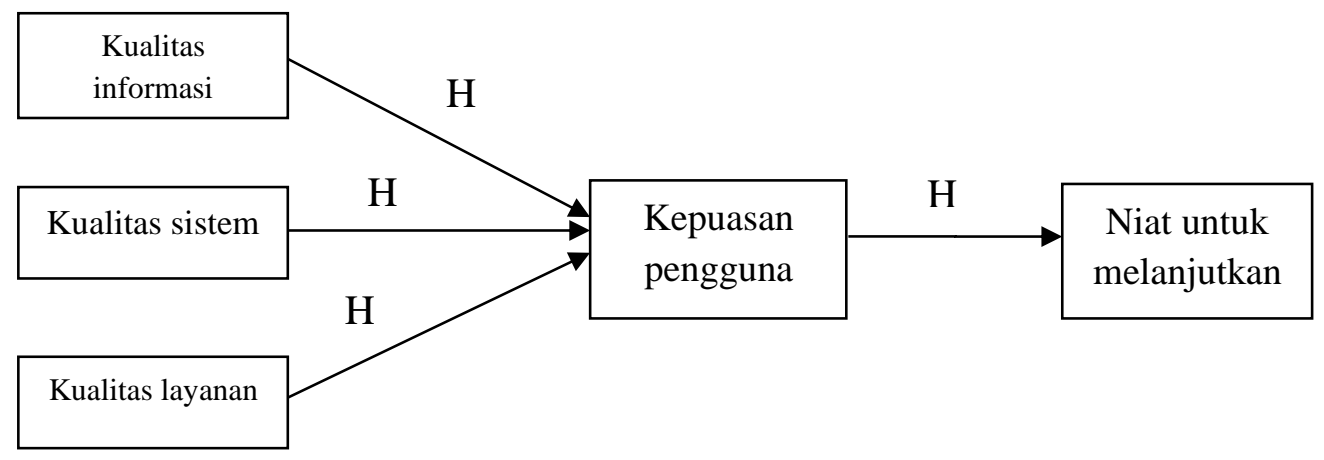

Gambar 1. Model Penelitian

\section{METODE PENELITIAN}

Jenis penelitian yang digunakan adalah penelitian causal. Jenis data pada penelitian ini adalah data cross-section. Obyek dalam penelitian ini adalah karyawan medis dan non medis pengguna sistem informasi RSUD Dr. Moewardi Surakarta yang berjumlah 420 karyawan. Teknik penyampelan yang digunakan adalah Two stages cluster sampling.
Pengujian alat ukur dalam penelitian ini menggunakan uji validitas dan uji reliabilitas dengan program SPSS. Uji hipotesis dalam penelitian ini dilakukan dengan analisis Stuctural Equation Model (SEM) dengan program AMOS.

\section{E. HASIL ANALISIS DAN PEMBAHASAN}

Pengujian validitas terhadap item pertanyaan kuisioner dinyatakan valid. 
Dimana semua item pertanyaaan mempunyai factor loading lebih besar dari 0,5 dan tidak terjadi nilai ganda. Maka dapat disimpulkan semua item pernyataan kuisioner adalah valid. Pengujian reliabilitas kuisioner diuji dengan menggunakan metode Cronbach Alpha ( $\alpha$ ) dengan nilai KMO sebesar 0,761 dimana semua item kuisioner dalam variabel yang diteliti mempunyai nilai reliabilitas lebih besar dari 0,6, sehingga dapat disimpulkan semua item kuisioner reliabel sehingga untuk selanjutnya item item pada masing masing konsep variabel layak digunakan sebagai alat ukur.

Pengujian asumsi normalitas data dalam SEM didasarkan pada normalitas secara multivariate. Data dikatakan normal

\begin{tabular}{cccc}
\hline Index & Output nilai & Hasil & Keterangan \\
\hline Chi square (X2) & Diharapkankecil & 171,213 & - \\
Goodness of fit index (GFI) & $\geq 0.90$ & 0,928 & Sangat baik \\
Root mean error of & $\leq 0.08$ & 0,029 & Sangat baik \\
approximation (RMSEA) & & & \\
Adjusted Goodness of fit index & $\geq 0.90$ & 0,897 & Marginal \\
(AGFI) & $\geq 0.90$ & 0,892 & Marginal \\
Tucker Lewis index (TLI) & $\geq 0.90$ & 0,912 & Sangat baik \\
Normed fit index (NFI) & $\geq 0.90$ & 0,986 & Sangat baik \\
Comparative fit index(CFI) & $\leq 2.00$ & 1,165 & Sangat baik \\
Normed chi square (CMIN/DF) & $\leq 0.04$ & 0,012 & Marginal \\
Root Mean Square Residual & & & \\
(RMR) & & & \\
\hline
\end{tabular}

Sumber : data yang diolah, 2016

Tabel 1. Hasil uji Goodness of fit

Hasil diatas menginformasikan bahwa model mempunyai goodness of fit yang sangat baik, artinya model sesuai atau cocok dengan datanya.

Uji hipotesis dilakukan dengan menganalisis hubungan sebab akibat (kasualitas) antar variabel dengan model berdasarkan nilai critical ratio (c.r) nya. Jika bila nilai Critical ratio (c.r) multivariate terletak dalam interval $-2,58<$ c.r $<2,58$. Uji normalitas dapat dilihat pada "Assesment of Normality. Dari hasil pengujian dalam output SEM nilai cr 51,972. Walaupun nilai normalitas multivariate melebihi dari syarat sebesar \pm 2,58 namun data yang digunakan dalam penelitian ini adalah data primer yang berasal dari jawaban responden yang sangat beragam, sehingga sulit untuk mendapatkan data yang berdistribusi normal multivariate secara sempurna.

Uji Goodness of fit dilakukan untuk menguji kesesuaian model dengan datanya. Hasil uji Goodness of fit dapat disajikan sebagai berikut : 
dapat disimpulkan variabel yang

Output SEM dapat disajikan pada tabel 2 dihipotesiskan berpengaruh signifikan. sebagai berikut :

\begin{tabular}{ccccc}
\hline Hipotesis & Estimate & C.R & P label & Keterangan \\
\hline NIAT $<---$ KEP &, 380 & 4,243 & ${ }^{* \star *}$ & Terdukung \\
KEP <--- KINF &, 265 & 2,520 & 0,012 & Terdukung \\
KEP <--- KSIS &, 565 & 3,413 & ${ }^{* * *}$ & Terdukung \\
KEP $<---$ KPEL &, 278 & 2,065 & 0,039 & Terdukung \\
\hline
\end{tabular}

Sumber : data yang diolah 2016

Tabel 2. Hasil Uji Hipotesis

Dari hasil, maka dapat disimpulkan :

1. Terlihat nilai $C R$ pada hubungan regresi antar variabel kepuasan pengguna dengan niat melanjutkan sebesar 4,243. Nilai ini lebih besar dari nilai $\mathrm{P}$ label nya, sehingga dapat disimpulkan ada pengaruh positif dan signifikan variabel kepuasan pengguna dengan variabel niat melanjutkan. Jadi hipotesis 1 terdukung. Hasil penelitian ini mendukung hasil penelitian yang dilakukan oleh Petter dan McLean (2009), Delon dan McLean (2003), Widiana et al. (2012).

2. Terlihat nilai $C R$ pada hubungan regresi antar variabel kualitas informasi dengan kepuasan pengguna sebesar2,520. Nilai ini lebih besar dari nilai $P$ label nya, sehingga dapat disimpulkan ada pengaruh positif dan signifikan antar variabel kualitas informasi dengan kepuasan pengguna. Jadi hipotesis 2 terdukung. Penelitian ini sejalan dengan penelitian yang dilakukan oleh Wu dan Wang (2006), Holsapple dan Le-post (2006), Petter dan McLean (2009), Radityo dan Zulaikha (2007), istianingsih dan Wijianto (2008), Tjakrawal dan
Cahyo (2010), Purwaningsih (2010), dan Fendini, et al (2013).

3. Terlihat nilai $\mathrm{CR}$ pada hubungan regresi antar variabel kualitas sistem dengan kepuasan pengguna sebesar 3,413 . Nilai ini lebih besar dari nilai $\mathrm{P}$ label nya, sehingga dapat disimpulkan ada pengaruh positif dan signifikan antar variabel kualitas informasi dengan kepuasan pengguna. Jadi hipotesis 3 terdukung. Hasil penelitian ini mendukung hasil penelitian yang dilakukan oleh Peteer dan McLean (2009), Holsapple dan Lee-post (2006), Tjakrawal dan Cahyo (2010).

4. Terlihat nilai $\mathrm{CR}$ pada hubungan regresi antar variabel kualitas layanan dengan kepuasan pengguna sebesar 2,065. Nilai ini lebih besar dari nilai $\mathrm{P}$ label nya, sehingga dapat disimpulkan ada pengaruh positif dan signifikan antar variabel kualitas informasi dengan kepuasan pengguna. Jadi hipotesis 4 terdukung. Hasil penelitian ini mendukung hasil penelitian yang dilakukan oleh Holsaplee dan Lee-post (2006), Wu dan Wang (2006), Kaihatu (2008), Petter dan McLean (2009). 


\section{F. KESIMPULAN}

Penelitian ini bertujuan untuk menguji pengaruh kepuasan pengguna sistem informasi terhadap niat untuk melanjutkan sistem informasi, menguji pengaruh kualitas informasi terhadap kepuasan pengguna sistem informasi, menguji pengaruh kualitas sistem terhadap kepuasan pengguna sistem informasi, menguji pengaruh kualitas layanan terhadap kepuasan pengguna sistem informasi. Hasil penelitian menunjukan kepuasan pengguna berpengaruh secara signifikan terhadap niat melanjutkan sistem informasi rumah sakit, kualitas informasi berpengaruh secara signifikan dengan kepuasan pengguna, kualitas sistem berpengaruh secara signifikan dengan kepuasan pengguna, kualitas layanan berpengaruh secara signifikan dengan kepuasan pengguna. Hal ini memberi makna bahwa semakin kualitas informasi, kualitas sistem dan kualitas layanan dapat meningkatkan kepuasan pengguna maka semakin meningkat niat untuk melanjutkan sistem informasi pada karyawan di RSUD Dr. Moewardi.

\section{G. IMPLIKASI MANAGERIAL}

Berdasarkan hasil penelitian semua hipotesis terdukung artinya variabel pembentuk kepuasan untuk membangun niat melanjutkan sistem informasi di RSUD Dr. Moewardi dapat dikatakan baik, namun untuk lebih memaksimalkan niat untuk melanjutkan maka masih diperlukan peningkatan kualitas informasi dengan cara sistem mampu memberikan informasi secara kekinian (up to date) meningkatkan kualitas sistem misalnya sistem dibuat mudah sehingga tidak menghabiskan waktu, memperbaikan isi tampilan - tampilan sistem sehingga mudah dipahami, dan meningkatkan kualitas layanan sistem informasi misalnya memberikan kejelasan, keamanan, efisiensi, dan ekonomis.

\section{DAFTAR PUSTAKA}

Davis, F.D. 1989. Perceived Usefulness, Perceived Ease of Use, and User Acceptance of Information Technology. MIS Quarterly, Vol. 13, No. 3, pp. 319-340.

Delone, W,H., dan E.R. McLean, 2003. The DeLone and McLean Model of Information Systems Success:A TenYear Update. Journal of Management Information Systems, Spring 2003, Vol. 19, No. 4, pp. 930.

Fasihat, D.U dan Ruspita. R.P. 2015. Pengaruh Kualitas Sistem Informasi Akuntansi terhadap Kinerja Perusahaan di Bank Pembangunan Daerah Daerah Istimewa Yogyakarta (BPD DIY) Syariah. Skripsi, Universitas Islam Negeri Sunan Kalijaga Yogyakarta. Unpublish

Groveer, V., Seung.R.J.,dan Albert. H. S.1996. Information systems effectiveness: The construct space and patters of application.Information\&

Management, Vol. 31, No. 4, pp. 177-191. 
Holsapple, C.W., dan A. Lee-Post. 2006. Defining, Assessing, and Promoting E-Learning Success: An Information Systems Perspective. Decision Sciences Journal of Innovative Education,Vol. 4, No. 1. pp. 60 -95

Ives, B.Margatreth. H. O., dan Jack. J. B. 1983. The Measurement of User Information Satisfaction.Center for Digital Economy Research Stem School of Business Working Paper IS-82-27.

Tjakrawala, F.X.K dan Cahyo, A. 2010. Adaptasi model Delone \& McLean yang dimodifikasi guna menguji keberhasilan implementasi software akuntansi bagi individu pengguna:studi empiris pada perusahaan dalam industry barang konsumsi yang terdaftar di bei. Simposium, Universitas Jenderal Soederman Purwakarta.Unpublish

Kaihatu,T. S., 2008. Analisa Kesenjangan Kualitas Pelayanan dan Kepuasan Konsumen Pengunjung Plaza Tunjungan Surabaya. Skripsi, Universitas Kristen Petra. Unpublish

Negash, S., Terry.R.,dan Magid.I. 2002. Quality and effectiveness in Webbased customer support systems. Information \& Management, Vol. 40, pp. 757-768.

Oliver, L.R, 1999. Whence Consumer Loyalty.Journal of Marketing, Vol. 63, pp. 33-44.

Parasuraman, A., Valarie. A. Z., dan Leonard. L. B. 1985. A conceptual
Model of Service Quality and Its Implications for Future Research. Journal of marketing. vol. 49, No. 4. pp. 41-50.

Petter, S. dan E.R. McLean. 2009. A metaanalytic assessment of the DeLone and McLean IS success model: Anexamination of IS success at the individual level. Information and Management, Vol. 46, pp. 159 - 166.

Purwaningsih, Susanti. 2010. Analisis Kesuksesan Penerapan Sistem Informasi pada Sistem Informasi Pelayanan Terpadu (SIPT) Online (Studi pada PT Jamsostek (PERSERO)).Aset, februari 2010 Vol. 12, No. 2, pp. $181-189$

Radityo, D dan Zulaikha, 2007. Pengujian Model DeLone and McLean Dalam Pengembangan Sistem Informasi Manajemen (Kajian Sebuah Kasus). Skripsi, Universitas

Diponegoro.Unpublish

Resita, N.I., dan Z.Baridwa. 2015. Determinan Individu Terhadap Pengguna Mobile Banking: Pendekatan Teknologi Acceeptance Model (TAM). skripsi, Universitas Brawijaya Malang.Unpublish

Sancaka, Mellisa., dan Hartono, Subagyo. 2014. Analisa faktor yang mempengaruhi penerimaan dan penggunaan kompas epaper oleh konsumen harian kompas di Jawa Timur dengan menggunakan kerangka Unified Theory of Acceptance and Use of Technology 
(UTAUT). Jurnal Manajemen

Pemasaran Petra Vol. 2, No. 2.

Van dyke, T.P., Leon A. K., Victor R. P. 1997.Measuring Information Systems Service Quality: Concerns on the Use of the SERVQUAL Questionnaire. MIS Quarterly.Vol. 21, No. 2, pp. 195 - 208.

Venkatesh, V., Michael. G. M.,Gordon. G. D., dan Fred. D. D. 2003. User Acceptance of Information Technology: Toward a Unified View. MIS Quarterly, Vol. 27, No. 3 pp. 425 -478 .

Widiana, M.E., Supit, H., Hartini, S. 2012. Penggunaan Teknologi Internet dalam Sistem Penjualan Online untuk Meningkatkan Kepuasan dan Pembelian Berulang Produk Batik pada Usaha Kecil dan Menengah di JawaTimur, Jurnal Managemen dan Kewirausahaan, Vol.14, No. 1, pp. 71-81.

Wu, J.H., dan Y.M. Wang. 2006. Measuring KMS success: A respecification of the Delone and McLean's model.Information \& Management, Vol. 43, pp. 728-7 